\title{
ANALYSIS OF AUDIENCE RECEPTION ON YOUTUBE TOWARD GENDER CONSTRUCTION IN THE MUSIC VIDEO IF I WERE A BOY BY BEYONCE KNOWLES
}

\author{
Ria Avriyanty
}

\begin{abstract}
Youtube is one of the favorite sites to share videos. Moreover, it facilitates the users to give a free and direct comment toward the videos they watch. The research examines the music video entitled If I Were $a$ Boy (2010) by Beyonce Knowles as well as the authentic responses from the viewers in Youtube. I argue that this music video creates a conventional gender construction which perpetuates the patriarchal norms in the society. As an attempt to give a new perspective on the similar kind of research, I do not stop at this point. Applying the concept of encoding-decoding by Stuart Hall (1973), I found the audience's being critical which can be seen from the total number of the responses and the controversy within. In accordance to the three hypothetical position argued by Hall, I found a different portion of the audience in each position. As a matter of fact, this phenomenon contributes to the cyber culture in which Youtube is seen as a functional space to make meaning of a digital text and negotiate with the constructed stereotype by giving responses.
\end{abstract}

\section{Keywords}

Youtube, Music Video, Encoding-Decoding, Gender Construction, Audience Position.

\begin{abstract}
Abstrak
Youtube adalah sebuah situs favorit di internet yang dapat menayangkan tayangan video. Selain itu, situs ini memfasilitasi pemirsanya untuk memberi komentar secara langsung dan gratis. Riset ini meneliti tayangan sebuah video yang berjudul If I were a boy (2010) karya Beyonce Knowles, sekaligus menerima respon dari para pemirsanya. Saya berpendapat bahwa video musik ini menawarkan sebuah konstruksi gender yang konvensional yang mendukung norma-norma patriarki dalam masyarakat. Sebagai upaya memberi perspektif baru pada riset mengenai topik ini, saya tidak berhenti disini. Saya mengaplikasikan konsep encoding-decoding dari Stuart Hall (1973). Saya menemukan pemirsa yang kritis memberikan sejumlah respon yang mengangkat kontroversi. Sesuai dengan tiga posisi hipotetis yang diajukan oleh Hall, saya menemukan porsi penonton yang berbeda pada tiap posisi. Dengan demikian, fenomena ini menjadikan budaya cyber Youtube sebagai suatu ruang yang berfungsi yang berarti dalam teks digital, dan bernegosiasi melalui respon-respon yang dilontarkan, menentang stereotip yang terkonstruksi.

Kata Kunci

Youtube, Music Video, Encoding-Decoding, Gender Construction, Audience Position.
\end{abstract}




\section{INTRODUCTION}

The song If I Were a Boy was one of the hits taken from the album "I Am ... Sasha Fierce" (2008) by Beyonce Knowles. It was written by Brittany Carlson and Toby Gad, while the music video (2010) was directed by Jake Nava and Beyonce herself. The video stars Beyonce Knowles, Eddie Goines (as Beyonce's couple), and Ryan Locke (as Beyonce's police partner). Sets in a black and white mode, it portrays the everyday lives of Beyonce and Eddie who live together in an urban area. The audience are shown to a restricted conflict of how they treat one to another as a couple. The main idea of this video talks about a shifting gender role. At the beginning, Beyonce is first depicted as a police woman who behaves badly toward Eddie, an ordinary employee. However, that kind of situation then appears to be her imagination of how she positions and acts like the opposite sex.

In analyzing a video music, one can not detach it from the song because the music, the dances, as well as the lyrics within are related one to another. In a similar vein, Carlsson (n.d.) argues that one of the basic function of video music is to visualize the lyrics of a particular song. Research on a video music is not something new to do even for the academic purposes. For example, Ridha Fauziah (2010) wrote her undergradute thesis about the analysis of the concept space and place in the music video by Michael Jackson entitled Black or White. After doing a small observation, I do not find an academic writing on the similar object of research, If I Were a Boy. However, there are some articles and reviews on the internet which also talk about this video. First, Spencer et al (2011) wrote a review that it contains of normative values that rule how boy and girl in general should behave. Beck and Smith (2008) saw it differently that they appreciated this video by giving comment to the collaborative acting between Beyonce as a musician and Eddie as an athlete of basketball player. All of which discuss the video music textually which focus on interpreting meaning, and I could agree to all. Here, I try to give a new perspective by giving another discussion about it. Throughout this essay I will also have a thorough analysis on what this video music want to say, and put another problem of research of how the audience in Youtube critically make meaning to it.

As one of the mostly visited sites, Youtube facilitates the audience to watch and upload many videos. Besides that, it allows the viewers to give responses toward the video they watch by writing a direct comment on the space provided. The fact is that the video music If I Were a Boy was also uploaded to Youtube by a user named BeyonceVEVO in 2010. There have been thousand of responses which consist of pros and cons regarding the conflict in this video. This phenomenon raises my curiosity to do an analysis beyond the textual approach, to see it from the audience perception as well. The argument presented is that this video music creates a conventional gender construction which triggers the ambivalent responses in Youtube. 


\section{ENCODING-DECODING BY STUART HALL (1973)}

Taken from his valuable writing "Encoding and Decoding Televisual Discourse", Hall (1973) contributed a significant breakthrough to media studies. This approach turns to be the answer to the traditional concept which had been criticized a lot for its linearity in delivering message. He argued that there are many factors and actors involved in creating, delivering and accepting the message in a particular programme on television. This is not a simple process as can be seen from his diagram (picture 1).

From the picture 1, the arrows show that each step is connected one to another. Similarly, During (1993) said that the created meaning in the production can always be found until the last step (90). However, the fact that these steps are depicted separately also shows that each process can be identified and analyzed independently. Throughout this essay, I will focus on the meaning structures only, which are Encoding, Programme as 'meaningful' discourse, and Decoding.

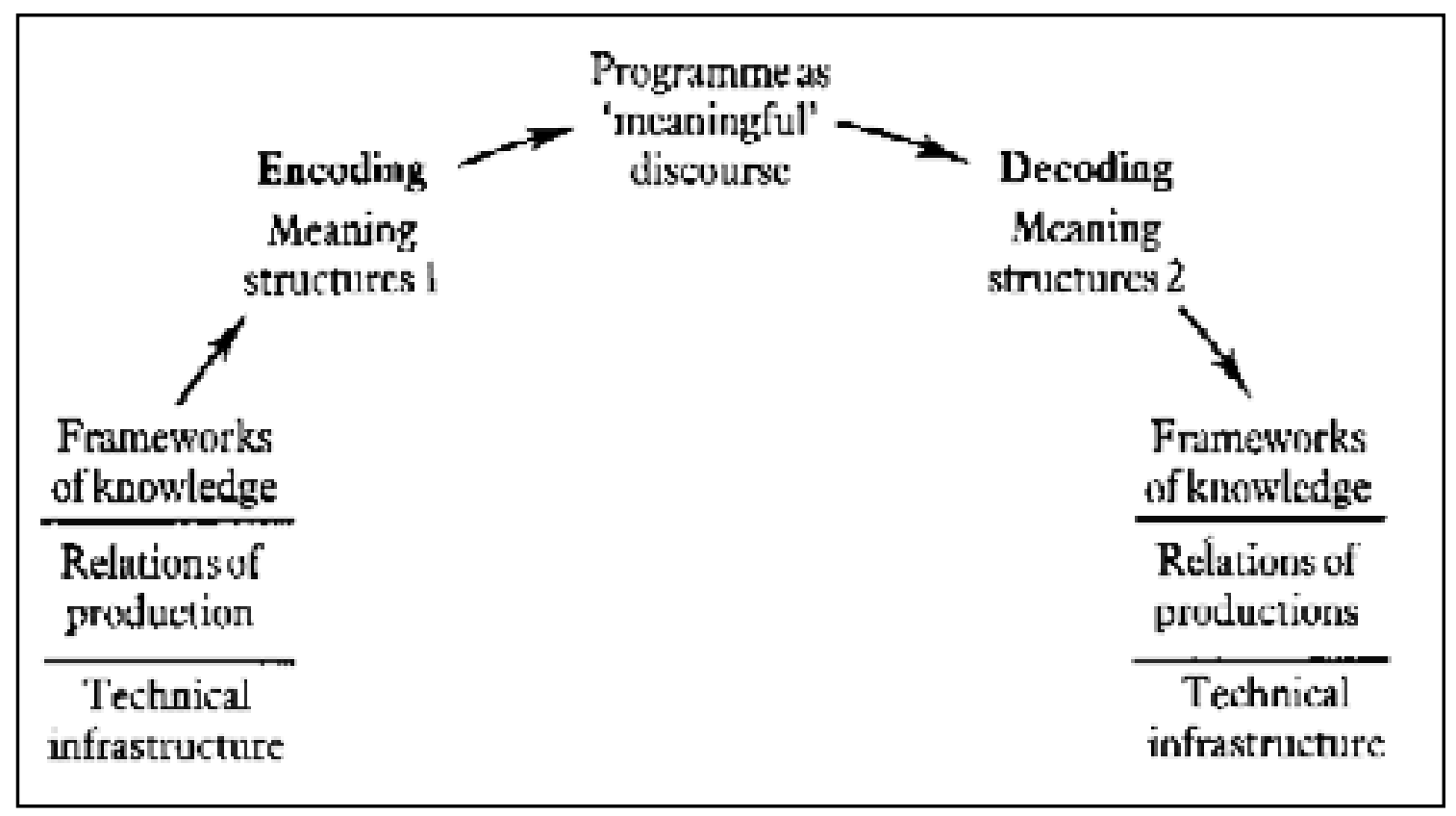

Picture 1. Hall's Encoding-Decoding Diagram (in Storey, 1996: 10)

The first meaning structure or what is called as encoding refers to the meaning from the program makers. Previously, they have gathered, chose, arranged, and decided what social values and phenomena to put on the program. Then, they are all arranged together to construct an intended meaning. In other words, meaning structure 1 is fully dominated and is seen from the perspective of the producer as the message sender. In the next step, that meaning is already packaged in a form of televisual programme as a discourse. This is the medium from which the audience interpret the text. Here the domination of the producers does not exist any longer because the text already has its 
own power from the languages and the images. Therefore, when the programme is already aired, the interpretation of the text fully depends on the audience as the reciever. This is related to the next stage in which the audience try to understand the text by decoding the message. This is again a complicated process because every single person has a different prior knowledge which may influence the way his or her interpret the programme. The responses toward the programme are called as meaning structure 2 .

From the point of view that each step can be detached independently, Hall also contributed another significant approach which is called as reception analysis. He analyzed the complexity of the audience from the way they see the text. In other word, the focus of the analysis shifts from the text to the audience. Hall proposed that responses from the audience can not be generalized whether it is right or wrong. All of which should be classified into three different position, which are dominant-hegemonic, negotiated, and oppositional. The first position is for the audience who affirm the text by accepting the text "fully and straight" (in During, 1993: 95). The next one is the combined position in which the audience are in between. Here, they accept and reject the codes at the same time. They affirm the dominant code within the text as a global value, while resist some others to adapt it with their local values. Storey (1996) added that the majority of audience belong to this position (13). The last grouping is the oppositional position which classifies the contradictive responses to the text. The explanation above will be apllied as the structure when I write the analysis later on. Besides that, I will also discuss the concept of gender stereotype which is found both in the video and the responses.

\section{METHODOLOGY}

The reason why I chose this particular video music as my object of research is due to the intriguing plot which could manipulate the viewers. The fact that Beyonce treats her couple terribly makes the audience claim her as a bad girl and builds a feeling of sympathy toward Eddie. Nevertheless, as the video reaches the end, this circumstance is switched to the other way round. This exchange will be discussed further by looking at the ideology of gender stereotype as well. In the discussion later on, I will capture some scenes and quote the dialogues from the video in order to support my argument. I will also look at the differences between the music video and the lyrics as the two similar-yetcontrasting productions.

The explanation above will be apllied in the frist section of my discussion in giving meaning to the text or what Hall (1973) called as the encoded message. The next section will be focusing on the decoded meaning of the text by analysing the authentic responses from Youtube. When I downloaded the video on 31 January 2012, there were 20.673 responses which were divided in to 21 sub-pages. Due to the limited time and space, I focus on the latest responses only to show that the video can still be attained up until recent days due to the relevant messages. Out of 400 responses which were 
written by 1 month ago, I reduce them into 100 responses which spesifically talk about gender issues. As I mentioned before that the analysis of these responses will be written based on the three hypothetical audience position by Hall (1973). The various responses also contain a controversy about gender issues which will be discussed along with the position of the audience.

\section{DISCUSSION}

\section{AMBIVALENT MESSAGES INTHE LYRICS ANDTHE MUSIC VIDEO}

Based on the type of music video proposed by Carlsson (n.d), the music video If I Were a Boy is classified as a combination clip between the performative and the narrative. It offers a naration or the story plot about the lyrics but also shows Beyonce's singing the song at the end. Carlsson (n.d) also says that analyzing a music video can not be separated from the lyrics because it functions to visualize the song. From that point of view, I can not leave the lyrics in discussing the video. Here, it is important to say that this essay will be more focusing to the video because the responses from Youtube are basically given toward the video itself not the lyrics.

The phrase If I Were a Boy as the title of both the song and the music video raises multiple interpretation. By looking at the grammatical structure, it obviously is the conditional statement which talks about an imagination of being a boy from the perspective of a girl. It is interesting to see what kind of boy depiction which is described both in the lyrics and the music video. Is it depicted exactly same? The best answer would be no, from which I could argue the ambivalent messages. I found a contradictive portrayal at the end of the story plot although some points are visualized simiarly.

I will first discuss the last part from both production which shows the contradictive gender ideology. In the lyrics, the song writers talk about girl empowerment as can be seen from the bridge below.

"It's a little too late for you to come back

Say its just a mistake

Think I'd forgive you like that

If you thought I would wait for you

You thought wrong"

As the song reaches the end, the situation shifts to the presents time. Here, the girl does not want to accept and forgive her boy who was doing bad before. The boy takes her for granted by assuming she will not leave him, but it is all wrong. The fact that the girl does not tolerate him any longer shows the indepency of a girl who does not want to be fooled. In other words, girl is depicted as an active agent who bravely express what she wants toward boy. 
On the other hand, the music videos visualizes them in a sort of totally different way. When that lyrics are articulated in the video, Eddie and Beyonce are just leaving a party. Soon after by the minute 00:03:35, there is additional dialogue in which they are arguing to solve their problems in the relationship.

Eddie : "You know... When you acted like that, I don't think you realize how it makes me look or feel."

Beyonce : "Act like what? Why are you so jealous? It's not like I'm sleeping with the guy?"

Eddie : "What?"

Beyonce : "What?"

Eddie : "I said.. I said why are you so jealous like I'm sleeping with the girls?"

Beyonce : (cry)

In analyzing the text above, I devided it into two sections, the reality and the imagination. The situation is still flipped when they utter the first two statements. Therefore, the first utterance is actually said by Beyonce who complains Eddie for treating her badly. This symbolizes Beyonce's effort in breaking something which prisons her. While saying this literally (statement 2), Beyonce imagines his refusal by slowly combing her hair and putting off her earrings (see picture 1). This second utterance is actually said by Eddie who laugh at Beyonce for assuming him to have an affair. This is because Beyonce never puts off her earrings as can be seen in the picture 2. In other words, she never stated that denial, but Eddie did.

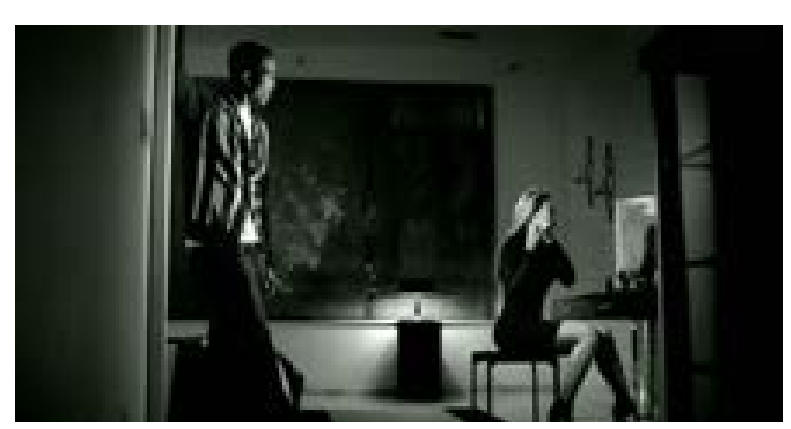

Picture 1. Beyonce is facing the mirror while putting off her earrings (00:03:38)

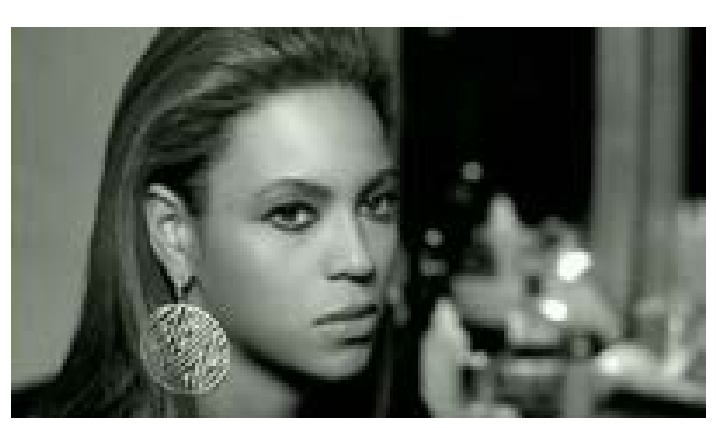

Picture 2. Beyonce turns out to still wear the earrings (00:04:05)

Since Beyonce said the word "what", the situation goes back to reality. There are some reason why I said so. First, there is a six second silence between the second what and the next utterance to inform the audience about a contextual shifting. Therefore, the last sentence is trully uttered by Eddie. Besides that, he repeats the word "I said" twice which shows his confirming what he already said before, that is statement 2 . It is interesting to see that at the end of the dialogue Beyonce did not say any thing but crying. This is somehow contrasting to her depiction in the lyrics as an expressive girl. Here, Beyonce is controlled by her boy who treats her badly without showing an effort 
to make a complaint. This is what I called different gender ideology raised in both production which triggers controversy in the video.

Besides the controversy, there is also a different set of rule for boys and girl in understanding faithfulness. From the dialogue above, boy assumes that girl does not need to be worry or jelaous to him as long as he does not sleep with other girls. As for girl, there are other behaviors besides that which are categorized as being not faithful. I will discuss further what they are.

All of the negative male stereotypes that Beyonce criticizes are shown in a form of her imagination of being a bad boy like Eddie. The first dichotomy can be seen from their distinctive occupation. As a police woman, Beyonce spends most of her working hours outdoor. She has to deal with masculine environment as represented by all male involved in the city scenes. She also arrests the burglar which symbolizes the cruelity of the city as well. Here, a girl is depicted to conquer the dominant power. On the other hand, Eddie is depicted as an employee who works in a futuristic office. Throughout the video, Eddie only stays in the same room and works with his computer only. Different from Beyonce, Eddie is in a safe area which is symbolized by the protection of the surrounded walls. This contrastive depiction deconstructs the conventional stereotype which says that "it has been common for women to be presented more in home setting and men in work setting" (Brabant \& Mooney, 1997; Furnham \& Schofield, 1986; Lovdal, 1989; McArthur \& Resko, 1975)." (dalam Schneider, 2004: 345).

Even when both of them are depicted in home setting, there is still a shifting gender stereotype. Tuan (1988) argued that home is one example of "local and intimate" place because people living there must have an emotional bound, such as a spouse (1988: 318). In accordance to the concept of gender and space, house is associated to the traditional place for girl. However, this video shows a different situation that Beyonce who "supposedly" stays at home leaves to work, even earlier than Eddie. The particular area of a house which is identified as a domestic area for girl is kitchen where the feminine activity like cooking occurs. At the beginning of the video, Eddie is busy in serving the breakfast for Beyonce who is just awaken. She just sips a glass of milk without having a seat to talk to him. From this situation, Beyonce imagines that boy could also be the agent who serves girl.

The most distinctive story plot which shows another shifting gender role can be seen from how Beyonce and Eddie deal with the opposite sex colleague. Cheating is something related as a negative male stereotype which is constrasted to the female characteristic as the faithful agent. On the contrary, Beyonce imagines herself as a girl who spends most of her time by going out with male cops intensively. This is related to her occupation which is dominated by male cops. In the picture 3, there is a scene where Beyonce helps Ryan from his back. 


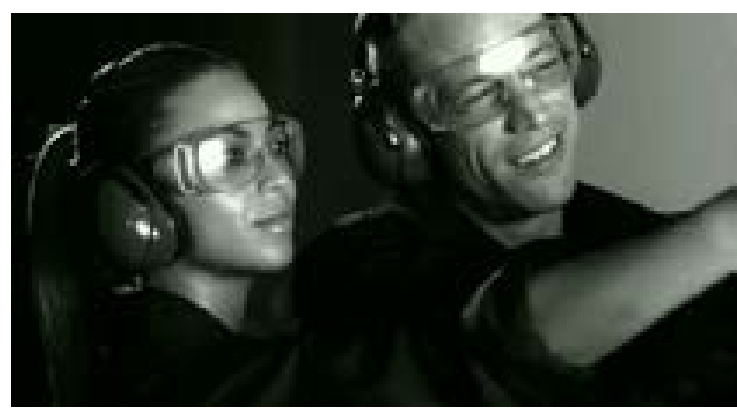

Picture 3. Beyonce and Ryan practice shooting (00:01:43)

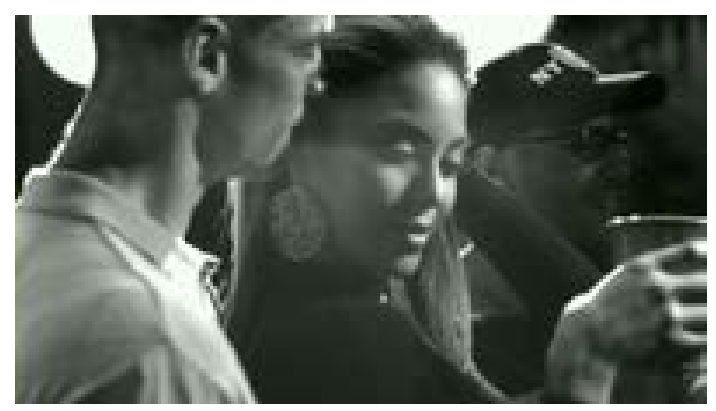

Picture 4. Beyonce and Ryan are dancing in a party $(00: 02: 49)$

Beyonce is the one who initiates helping Ryan because he is not depicted in a difficulty. Therefore, this can be said as her effort to get closer to Ryan who simultaneously responses her. He once drops by Beyonce from her house to get to the office together, and brings her a cup of hot cofee. This close friendship also happens out of working hours, such as having dinner together. In fact, there are other colleagues involved in that moment, but Beyonce still shows her affection by having a seat next to him. At that time, Beyonce rejects a phone call from Eddie as the visualization of the lyric which says "If I Were a Boy, I would turn off my phone." This shows that Beyonce prioritizes Ryan and her individual pleasure more than her couple. Besides that, the intimacy between Beyonce and Ryan can be seen from the scene in a party where they are dancing together. Ryan also whispers some words to Beyonce softly as can be seen in the picture 4 . The explanation above show that their relation tends to be too closed as the work mates.

On the other hand, Beyonce imagines Eddie as an ideal couple who is faithful as can be seen from his attitude at office. While working, Eddie still puts her attention to Beyonce by planning a surprise gift that he buys from the online shops. The fact that he keeps on calling Beyonce by phone also shows his loving care.

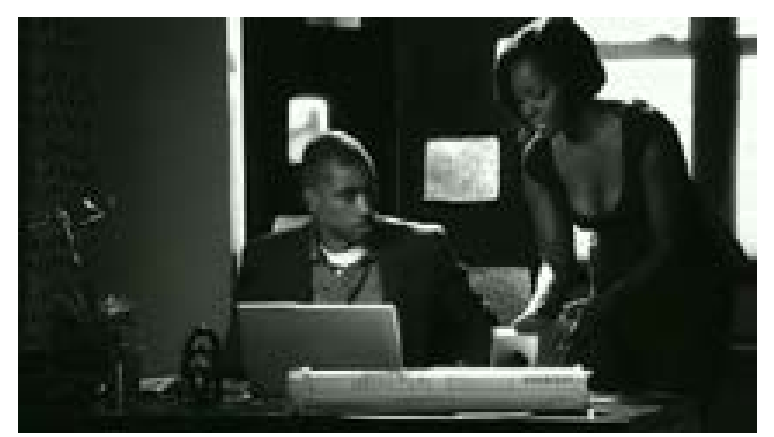

Picture 5. The coming of Eddie's female colleague (00:01:15)

Even when there is an intervention from the outsider, Eddie does not betray his couple. In picture 5, it can be seen that there is a female colleague coming to Eddie's 
desk. She brings some document for Eddie to sign. Besides that, she also symbolizes the temptation as can be seen from her sexy attire which is not likely to wear in office. Moreover, her bowing gesture shows her as a teaser. In that case, Eddie rejects her and backs to his work straightforwardly. It can be said that when Eddie is given an option to cheat on Beyonce, he does not choose to do so. After works, Eddie also refuses an invitation to go home together because he has not finished his work yet.

From the description above there is a contradicting attitude from Beyonce and Eddie in dealing with the opposite sex mates. However, it is important to say that these are all not the real situation. When the video almost reaches the end, the lyric is written in the present tense. Therefore, it is clear that Beyonce is the one who works at the office, and Eddie is the male cop. Moreover, Beyonce keeps being faithful and nice to Eddie who takes her for granted. Apart from the shifting gender roles at the beginning, it turns out that boy is still portrayed as the dominant agent toward girl.

Beyonce represents a charater of a desperate girl who can not do anything toward boy. As a matter of fact, she has been through a complicated process that she finally feels under controlled. At first, she imagines to replace her position as Eddie who treats her badly and wish for him to be a better man. By having a delutional world of her own, Beyonce does not have a courage to express what she feels in the real life. Even when she literally talks to him, as can be seen from the dialouge at the beginning of my analysis, Beyonce cries when Eddie denies her complaint. Overall, this video leaves a depiction of a girl as the powerless agent. The unequal description of this sort becomes the basic reason why there are many debatable comments arise.

\section{YOUTUBE RESPONSES AND THE HYPOTHETICAL AUDIENCE POSITION BY HALL} (1973)

Before writing a further discussion about the responses from Youtube, I will give a bit background about the online users. Sherly Turkle (1995) stated that internet is "the world without origins" (in Baran, 2004: 325). This is related to the identitiy of the users which may not be factual. To avoid a speculation, I will be more focusing to the content than the user name as the identity. For example, I could say whether the user is a girl or a boy when it is stated literally. Out of the 100 users involved in this reasearch, there are 35 males, 35 females, and 30 users who are categorized as genderless. Here, I will not discuss the whole responses because of the limited time and space. For further reading and more complete discussion, you can take a look at my undergraduate thesis on the same title. All the responses used are the authentic version from Yuotube, so mispells and slang words might exist.

From the first classification that I have made, there are several thematic categories made. I also found that some of them talk about general gender issues which is not found in the video, such as homosexuality. In analyzing the responses, however, I classify them 
based on the audience position argued by Hall (1973) as below.

\section{DOMINANT-HEGEMONIC POSITION}

In this position, audience give an affirmation to the message that they agree to. I found 51 users belong to this group, which consist of 24 females, 15 males, and 12 unknwon users. The first code is the depiction of a powerless girl who is represented by Beyonce at the end of the video. A female user says, "This song represents every girl that is controlled by their boyfriends and husbands" (preemlhery). The word "every girl" indicates a generalization that all girl experience the same feeling in a relationship. Having it written in a passive form shows inequality in which boys have a power to control girls. Moreover, there is a different status of boy, as boyfriends and husbands. This implies that even in a different kind of relationship, girls are treated in the same way.

Some users relate this condition to a more general problem, such as family and biological matters. Rawrlikeababy stated that "If I Were a Boy my dad would love me ! :/ lifes lifes." The female user imagines of being the opposite sex to be accepted in the family. It implies that there is a gender inequality about being a daughter and a son. In this case, father becomes the agent who controls a daughter life. The emoticon and the additional word in the last sentence ":/ lifes lifes" shows a complaint that she can not do a thing to make a change. This following user relates the video to the biological problems which is regularly experienced by girls, "i sing this song whenever im having my period. cuz. YOU DONT KNOW HOW IT HURTZZZ Dx" (RaeRae0914). Here, the female user compares the portrayal of a girl who is hurt by her bad boy to the physical pain in her monthly period. Although it refers to a different context, both situation position girl as the powerless agent.

The next point which is accepted by most of the users is the code of negative male stereotype. In other words, they affirm the character of Eddie as a bad boy who represents the behavior of a boy in general.

\footnotetext{
"BOYS ARE STUPID

THROW ROCKS AT THEM"

zooski90 1 month ago
}

From the context of the video, the word stupid here does not related to the intelectual ability which is determined by the rank of one's intelegence. However, they are said to be stupid because of their bad behavior to not understand girls. In the comment above, boys are claimed to be the stupid agent. The phrase "THROW ROCKS AT THEM" can not be taken literally because it just symbolizes a feeling of hatred to boys. Another user shows her favour literally as follow, "this video is so true!! men just dont get it..... and NEVER will!!!!" (niamh256). The word it refers to what girls want from 
boys, as represented by Beyonce's wish for Eddie. However, boys do not understand this feeling. Moreover, she adds the words "NEVER will" which shows impossibility for boys to do so. This implies an assumption that being ignorance is a part of male characteristic. Another user also relates this negative male stereotype to a more spesific manner which claims boy as a free sex doer. "If I was a boy, I'd whip my penis out every where...." (facebookprincess16). Being the opposite sex, she imagines of having a different genital literally. Hence, this response includes biological changes as well. Eventhough the form of her imagination is different from what Beyonce does, there is still a similar negative value. Here, male is represented as a free sex oriented character.

Affirmation to the code of male negative stereotype is also written by the male users, but they shows two distinctive attitudes toward it. The first group accepts what they see on the video in a good deed.

"so grateful for this song, it made me feel so guilty. and imma boy. hard to believe. sorry girls i get it now.!!!" monksdfc 1 month ago

The male user above comments to the picture of a bad boy in Beyonce's real life as something true. From this video, he sees the problem from a different perspective which realizes him about the way he treats his couple. At last, this video teaches him to have a better way in understanding girls. On the other hand, another male users shows an ignorance to the text.

"Men are not monogamous by nature. Our male ancestors by instinct tried to get as many females of our same species pregnant to continue the species and life, its the nature. That is why so many men cheat on women. And that is why so many guys watch porn, it is basically another way of satisfying the instinctal drive to mate with as many women as possible"

MarryTheNightReplay 1 month ago

The user above confirms that boys are stereotyped as cheaters, but he claims it as something usual. It is because they naturally could not live with one couple only. In other words, there is a negative stereotype which is internalized within the male body. Therefore, having an affair with some girls is seen as something common. Besides that, the language used in that response lessen the negative value of cheating for it is written as "to mate with as many women as possible". This again symbolizes that he does not see this behavior as something wrong.

The last code which is affirmed is about the character of Eddie in the beginning of the video as powerless figure. Different from the previous affirmation, there are only two responses from male users who talk abouth this issue. One of them is stated by thedani951, "I don't know why but i feel sometimes like that boy from the clip, when my girlfriend makes me jealous, I know she don't think how i act or how i feel . :-<." 
The user identifies himself as Eddie who is hurt by his couple. He affirms what Eddie feels because he experiences the same situation although he was first doubt about that. It implies that what occurs in Beyonce's imaginative world really happens in one's life.

\section{NEGOTIATED POSITION}

The second position argued by Hall (1973) is the position in between when the audience do a selection to the text. They affirms some points while rejects other at the same time. There are 33 Youtube users classifed in this group with 7 female, 11 male, and 15 unknown users. Different from the dominant audience who talk about various codes, the negotiated users only discuss the code of faithfulness.

In the first category, both the female and male users negotiate to the negative stereotype of boys as cheaters.

I understand how girls say that every guy is like this...But thats not correct! There are some good guys out there, but somehow we just end up with the bad guy :(

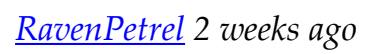

Although the user realizes that there are some bad boys out there, she rejects the depiction of it in the end of the video. She understands that most of girls will agree to Beyonce who blames on boys, but she does not fully accept it. There are two different concepts of boys in this response. As she affirms the text, she refers to a group of bad boy who is represented by the character of Eddie. At one side, she believes that there are still some good guys who meet girls' expectation. Similarly, the male user also gives the similar comment, "Not all guys are like this. Some of us are actually not assholes" (niggledafiggles). The user identifies himself using the word us which also refers to boys in general. He rejects the negative stereotype as can be seen from the word this. He critically realizes that this video intentionally constructs a depiction of a boy who confirms the negative stereotype in the society. Thus, he mentions Eddie as asshole. He also rejects this representation to avoid a generalization toward boys.

Other users affirm this negative stereotype as well, but they provide a further distinction. Yafidafil said, "the point is if $\mathrm{i}$ was a boy not if $\mathrm{i}$ was a man real men dont treat women like this boys act this way not men." The user classifies male as a boy and man. In the Oxford Advance Learner's Dictionary of Current English, the word boy means a young male person, while man refers to an adult male human being. Therefore, I can say that what makes both of them different is simply the age that boy is younger than man. However, in the response above, age does not really matter because the distinction refers to the way a boy or man treats his couple. In short, it talks about a psychological maturity more than biological changes. The audience undertands very well that the male character here is described badly, and he accepts that. However, that kind of characteristic belongs to boys because they do not know how to treat girls. This is related to the title and the 
lyrics which clearly say If I Were a Boy. Then, the audience brings an alternative as a rejection that a man will not do such a thing because he is mature enough. By giving these two concepts, the user wants to emphasize that the depiction of a boy as cheater is true, but it does not go for man.

Subsequently, audience negotiate to the code of male as cheater by not taking sides. "this shows that whether you're a man or woman, you can still hurt someone deeply by taking advantage of them and playing with their feelings."

urgandma 1 week ago

From the response above, it can be seen that the audience may confirm the description of bad boy. However, it is also provided with comment that girls can do the same bad thing. Thus, there is not any agent to blame on. Basically, this comment does not emphasize to the subject, either boy or girl, but more to the negative behavior. This video music gives two similar condition whenever one does not treat the couple well. In short, the audience wants to say that having an affair is not related to a particular gender trait.

\section{OPPOSITIONAL POSITION}

The last position proposed by Hall (1973) classifies the oppositional audience who reject the text because of another references. The total number of Youtube audience who belong to this group is 16 who are 4 female, 9 male, and 3 unknown users. In general, the audience give the resistance implicitly by giving a constrative alternative. The first group of audience in this position basically rejects Beyonce's imagination. As can be seen from her response, truleywolfina argued that "naturally girls are smarter than boys, so why would she want to be a boy for a day??? and if she was a boy she wouldnt have the same voice." The female user above indirectly rejects the imagination on the video because she feels fine of being a girl. In terms of intelegency, she adds that girls are smarter than boys. Thus, a girl imagining to be a the opposite sex does not make any sense.

The subsequent type of audience shifts the imagination to the other way round. Here, it is mostly stated by the male users who imagine themselves as the bad girls. One example can be seen as follow.

IF I WAS A GIRL!!!! i would cook for my guy (not mcdonalds or any fast food), i would not say a thing if he dranked a couple of beers after work.... $i$ would not go shopping with my girls everyday and just wasted alot of money....IF I WAS A GIRL!!! i would dress sexy as f*ck for my man and f*ck him every night ....but ur just a girl hsxkillaz1 1 month ago

The male user still counts on the patriarchal norms in determining the concept of ideal girl. In doing the analysis to the resonse above, I devide it into two separate discussion, which are the description of a girl as an individual agent and as a couple. 
When a girl goes shopping and makes friends, it is seen as the irrational activities because of the wasted money and time.

As an ideal couple, girl is stereotyped as the inferior agent who must be equipped with the domestic feminine ability like cooking. This is merely aimed to serve boy's need. On the other hand, boy positions himself as an uncontrolled agent who is free to do anything he likes, including get drunk. Eventhough the activity seems to break the social rules, it is not allowed for girl to give complaint. Again, it is because girl does not have power to do so. The last characteristic is that girl is stereotyped as the sexual object to please boy. One way to do that is by wearing sexy dress. All of hese traits are seen from the perspective of a boy which implies that a negative imagination can also be done toward girl.

The last code which is rejected is the depiction of bad boys. Both female and male users have the same point, but they deliver it in a different way. McMichael17 said, "Does anybody else feel like this is really sexist against boys...? She's calling us all stupid and cheaters... I don't like beyonce." He delivers a protest to the video which puts boys as the agent to blame on. The word "us" is used to identify himself and boys in general which are stereotyped negatively. The word stupid here arises multiple interpretation. It is either the characteristic of a boy who does not understand how a girl feels or the fact that boy is fooled by girl who has an affair. Apart from that, it is interesting to look at the last part of the responses that the audience show his personal anger to Beyonce. This again could be ambiguous that the word Beyonce could first refer to her as a person. Besides, it also possible to be a way for the user showing his disapproval to the text by mocking Beyonce as the musician.

As another form of rejection, the sudience gives an example of a good boy as the contrastive alternative. RonnieJones14 wrote, "My boyfriend cares how it hurts and he does everything to make sure im never stuck in a position like that!" Here, she thinks that her couple as the ideal boyfriend which implies that not all boys are bad like Eddie. Besides that, another way can be seen from the fact that the response is written on the contrary to the lyric. For example, the phrase "My boyfriend cares how it hurts" derives from the lyric "You don't care how it hurts." By ommiting the word "don' $t$ ", it give a positive value that there's a good boy who treats girl well. Although she is not literally disagree to the video, she wants to show an example of a good boy to refuse the negative male stereotype in the video.

\section{CONCLUSION}

This essay attempts to focus on how the music video If I Were a Boy (2010) by Beyonce Knowles constructs a conventional gender stereotype which later triggers a debatable comments on Youtube. Since a production of music video is not separated from the song and the lyrics, I have tried to compare both of them. As a result, there is an 
ambivalent message for both of them discuss a different gender ideology at the end. The music video conveys a more conventional one that blames on boys as cheaters. As for the online responses, I have to say that basically Youtube is seen as a space to negotiate with the constructed stereotype. Here, the audience feel free to deliver their opinion which turns out to be huge and diverse. It is found that those responses meet the three hypothetical audience position by Hall (1973). However, there is a significant difference that the majority is classified in the dominant position not negotiated. In each position, I do not find a particular pattern of boys and girls audience in the relation to the code they interpret. In fact, there are the same codes which belong to different position becuse of different interpretation. This inconsistency proofs that a text could be seen from several ways in getting its meaning, and it fully depends on the audience. It is also found that they do not always decode a text as a whole. Some of them do it partially, such as by referring only to the beginning scenes. The question like the role of audience social background in giving comment may arises, bu it no doubt requires a further research on that. Overall, it is interesting to see that Youtube has a distinctive role as an online media for the users to communicate in digital world.

\section{REFERENCE LISTS}

\section{PRINTED SOURCE}

Baran, J. S. Introduction to Mass Communication: Media literacy and culture (3rd ed.). New York: McGraw-Hill. 2004.

During, S. (Ed.). The Cultural Studies Reader. Encoding, Decoding. New York: Routledge. 1993.

Fauziah, R. Representasi Identitas Ras di Amerika Serikat dalam Video Musik 'Black or White' Karya Michael Jackson. Skripsi. Depok, Universitas Indonesia. 2010.

Hall, S. "Encoding/Decoding", in D. H. Stuart Hall (Ed.), Culture, Media, Language. New York: Routledge, 128-138. 1980.

Morley, D. Television, Audiences, \& Cultural Studies. London: Routledge. 1992.

Saraswati, A. "Keterpenjaraan Perempuan dalam Ruang Kota di dalam Lost in translation (2003) dan The Good Girl (2002)". Wacana Vol. 11 No. 1, 143-158. 2009.

Schneider. J. D. The Psychology of Stereotyping. New York: The Guilford Press. 2004.

Storey, J. Cultural Studies \& The Study of Popular Culture: Theories and Methods. Edinburgh: Edinburgh University Press. 1996.

Tuan, Yi-Fu. "The city as a moral universe," American Geographical Review Vol. 78 No. 3 (July): 316-324. (Http://www.jstor.org/stable/ 215004), diakses pada 31/03/2012 14: 09. 1988. 


\section{DIGITAL SOURCE}

Beck, M., \& Smith. J. S. Production Change: "If I Were a Boy" Video From Beyonce Featuring Eddie Goines. http://www.nationalledger. com/pop-culture-news/production-change-if-iwere--213409.shtml, diakses pada 09 April 2012 pukul 12:13 WIB. 2008.

Biography. http://www.beyonceworld.net/about/biography/, diakses pada 05 Februari 2012 pukul 17:07 WIB.

Carlsson. S,. E. (n.d.). Audiovisual Poetry or Commercial Salad Image: Perspective on music video analysis. http://filmsound.org/what-is-video-music/, diakses pada 02 Maret 2012 pukul 10:05 WIB.

"If I Were a Boy" lyrics. http://www.azlyrics.com/lyrics/beyonceknowles/ ifiwereaboy. html diakses pada 31 Maret 2012 puku 12:57 WIB.

Knowles, Beyonce. "If I Were a Boy." I Am...Sasha Fierce. Beyonce Knowles. Jake Nava, 2009. Youtube. http://www.youtube.com/watch?v= AWpsOqh8q0M \&ob=av3e, diakses pada 31 Januari 2012 pukul 20:05 WIB.

Lamb, B. (n.d.). Beyonce - "If I Were a Boy." About.com Guide. http://top40. about. com/od/singles/gr/beyonceboy.htm, diakses pada 09 April 2012 pukul 12:03 WIB.

Spencer, et al. (2011). Gender Analysis "If I Were a Boy. http://gendersex.net/gendernorms/guide/gender-analysis-if-i-were-a-boy/, diakses pada 09 April 2012 pukul 11:54 WIB.

\section{APPENDIX}

\section{IF I WERE A BOY LYRICS}

[Verse]

If I Were a Boy

Even just for a day

I'd roll outta bed in the morning

And throw on what I wanted then go

Drink beer with the guys

And chase after girls

I'd kick it with who I wanted

And I'd never get confronted for it.

Cause they'd stick up for me.

[Chorus]

If I Were a Boy

I think I could understand

How it feels to love a girl

I swear I'd be a better man.

I'd listen to her

Cause I know how it hurts 
When you lose the one you wanted

Cause he's taken you for granted

And everything you had got destroyed

[Verse]

If I Were a Boy

I would turn off my phone

Tell everyone it's broken

So they'd think that I was sleepin' alone

I'd put myself first

And make the rules as I go

Cause I know that she'd be faithful

Waitin' for me to come home (to come home)

[Chorus]

If I Were a Boy I think I could understand

How it feels to love a girl

I swear I'd be a better man.

I'd listen to her

Cause I know how it hurts

When you lose the one you wanted (wanted)

Cause he's taken you for granted (granted)

And everything you had got destroyed

[Bridge]

It's a little too late for you to come back

Say its just a mistake

Think I'd forgive you like that

If you thought I would wait for you

You thought wrong

[Chorus 2]

But you're just a boy

You don't understand

Yeah you don't understand

How it feels to love a girl someday

You wish you were a better man

You don't listen to her

You don't care how it hurts

Until you lose the one you wanted

Cause you've taken her for granted

And everything you have got destroyed

But you're just a boy 